\title{
LA ESCULTURA COLONIAL GUATEMALTECA EN MÉXICO
}

LUIS LUIÁN MUÑ̃Z

\section{Introducción}

La escultura colonial guatemalteca," particularmente la de la época del auge barroco (1676-1795), gozó de merecida fama en la Nueva España. Empero, fuera de su ámbito y del Reino de Guatemala, vale decir los actuales países de Centroamérica y el estado mexicano de Chiapas, fue y es poco conocida. Efectivamente, nuestra escultura ha tenido lo que podríamos llamar una mala prensa, de manera que ni en España, ni en Sudamérica, es conocida y valorada. Lo contrario sucede con la estatuaria quiteña e incluso con la mexicana, respecto de las cuales no creemos pecar de exagerados si afirmamos que la nuestra es, en general, mejor que ambas, pese a lo cual, insistimos, apenas se le conoce fuera de nuestras fronteras.

Antes de entrar en materia, debemos situar históricamente lo que fue el importante Virreinato de la Nueva España, con toda su pujanza económica y cultural y su vecino, el Reino de Guatemala, que abarcaba desde el sur del istmo de Tehuantepec hasta la actual Costa Rica. Es evidente que su cercanía y comín tradición precolombina hacía que ambas fuesen parte del área de alta cultura que los especialistas han denominado Mesoamérica. Durante el periodo colonial existieron estrechos vínculos políticos, culturales, económicos y religiosos, lo que explica fácilmente la presencia de obras de arte e incluso de artistas guatemaltecos en México y de obras de arte y artistas mexicanos en Guatemala. A manera de ejemplos podría mos mencionar el nombre de Lucas Méndez, que de acuerdo con un historiador poblano, era guatemalteco, arquitecto de retablos y según parece escultor, autor del Retabio de los Reyes de la catedral de Puebla, to que lo sitúa como introductor de la columna salomónica nada menos que en Puebla de los Ángeles,' pues concluyó dicho altar en 1649 e hizo el altar mayor

\footnotetext{
* Una parte de este trabajo fue presentada en el Simposio Latinoamericano sobre Arte Sacro, celebrado en México, D. F., del 10 al 12 de octubre dee 1984,

I Desafortunadamente, se desconoce mucho sobre este artista que fuera tan importante para Puebla. Sabemos, por el Dr. E. Castro, que era oriundo de la provincia de Nicaragua, en el Reino de Guatemala. Nació a principios del siglo XVII y falleció a fines del mismo. Algo de eso mencionamos en "Apuntes sobre las relaciones entre Santiago de
} 
de la iglesia de Santo Domingo, anterior al existente ahora, en la misma urbe. En Guatemala, a fines del siglo XVII, sabemos de la presencia del arquitecto de retablos y escultor Agustín Núñez, quien en su declaración, hacia 1687, cuando se le nombra arquitecto mayor de retablos, manifestaba ser de Oaxaca. Uno y otro son testimonio de este intenso intercambio estético, como lo son, asimismo, la profusa cantidad de pinturas mexicanas en Guatemala y de esculturas guatemaltecas en México. ${ }^{2}$

No es difícil recordar la abundancia de pinturas de Cristóbal de Villalpando (1649-1714), particularmente de su serie, impresionante en número y dimensiones, de la vida de San Francisco de Asís que adornara el claustro franciscano; ${ }^{3}$ el apostolado que perteneciera a la catedral metropolitana realizado por su amigo mulato, Juan Correa (activo en la 2a. mitad del siglo XVII) ${ }^{4}$ igualmente autor de varias pinturas de arcángeles en la iglesia de Concepción Ciudad Vieja. La copiosa serie acerca de la vida de la Virgen María que se encuentra también en la catedral metropolitana, como los interesantes cuadros acerca del triunfo de la Iglesia y de la Eucaristía, con influencia de Pedro Rubens, y que fueran todos ellos encargados a Pedro Ramírez (activo en la 2a. mitad del siglo XVII), pintados en México para el nuevo edificio catedralicio, que se inauguraría en 1680. A estos tres importantes nombres, se podrían añadir los de Josephy de Páez, la familia Rodríguez Juárez y Miguel Cabrera, (1695-1768), de quien conocemos diversas pinturas en Guatemala, desde luego ya en pleno siglo XVIII. ${ }^{5}$ Por consiguiente, no es de extrañar que muy numerosas esculturas guatemaltecas, particularmente de la época barroca, vale decir

Guatemala y Puebla de los Ángeles, en la colonia". Antropología e Historia de Guatemala, Vol XX, No. 2 (julio-diciembre 1968), p. 36.

${ }^{2}$ Otto aspecto en que creemos pueda pensarse en importaciones de Guatemala, es en lo referente a los Cristos hechos de médula de caña de maíz, llamados de tuza en nuestro país. Existe uno en la iglesia de San Francisco de Antigua Guatemala, aunque se le asigna como autor a fray Félix de Mata, y hay otro Cristo que se dice ser de cuero, en la iglesia de San Martín Jilotepeque, qua acaso también sea de tuza.

${ }^{3}$ Mayor información sobre este tema puede encontrarse en nuestro trabajo: La pintura de Cristóbal de Villalpando, en Guatemala, Guatemala, Edita, 1983, y en Anales del Instituto de Investigaciones Estéticas de la UNAM.

4 Recientemente hemos localizado una pintura de la Virgen de Guadalupe, firmada por Correa, en la sactistía de la iglesia, la más temptana que existe aquí, si bien desgraciadamente no está fechada. Actualmente se le trasladó a la iglesia del antiguo poblado de la Villa de Guadalupe, ahora incotporada a la capital.

5 Sabemos de dos miniaturas hechas por el extraordinario tetratista guatemalteco Francisco Cabrera (1781-1845) de los personajes mexicanos Matcelo Arrollo y su hijo José Miguel Arrollo Toledano, secretario de la Legación de México en Guatemala, en 1834, que parecen haberse confundido con obras del pintor Miguel Cabrera. Forman parte de la donación de la señora Santín de Fontoura al Museo Nacional de Historia de México. Véase Boletín del INAH, Época II, abril-junio, 1972, p. 49. 
de la segunda mitad del siglo XVII, del XVIII y aún del primer tercio del siglo XIX, se encuentren en México. La diferencia estriba en que la escultura religiosa era anónima y, en su inmensa mayoría, de pequeñas dimensiones, evidentemente por su facilidad para ser transportada y la escultura mayor sería de vestir o bastidor, por esa misma razón.

\section{Dos devociones religiosas guatemaltecas en México}

Trataremos de aludir muy sucintamente a dos devociones religiosas de origen guatemalteco, que se difunde por el norte del territorio del antiguo Reino de Guatemala y consiguientemente a Chiapas, en el caso del culto a la muerte, conocido con el nombre del Rey San Pascual, en Guatemala, y San Pascualito en Chiapas, primordialmente en la región de Tuxtla Gutierrez. El otro culto es más antiguo y su origen está en la población oriental de Esquipulas, departamento de Chiquimula. ${ }^{6}$ Su ámbito devocional es mucho mayor, pues abarca gran parte de lo que fue el mencionado Reino de Guatemala, pero se disemina por muchas poblaciones de México e inclusive llega hasta el actual Estados Unidos de Norteamérica. Naturalmente por razones de espacio, simplemente haremos muy breves referencias de ambas devociones, pero remitimos a los lectores interesados a trabajos especializados ya publicados. ${ }^{7}$

Comenzaremos por mencionar el surgimiento del culto al Señor de Esquipulas, devoción bastante difundida en la Nueva España y que debió surgir y propagarse a lo largo del siglo XVII y en los siglos XVIII y XIX, toda vez que está perfectamente documentada su hechura por Quirio Castaño a una cofradía de indígenas de dicha población, para $1595 .^{8}$ Respecto a la difusión del culto al Señor de Esquipulas, población de Chiquimula, en el oriente de Guatemala, diremos que alcanzó gran popularidad no sólo en el ámbito de lo que fue el Reino de ese nombre, sino que trasciende hacia el sur hasta Panamá, ${ }^{8 a}$ y en Norte a lo que era el Virreinato de la Nueva España, particularmente desde finales del siglo XVII.

${ }^{6}$ Según Samuel K. Lothrop, dichó culto pudo tener un origen precolombino, relacionado con Ek.Chuah, dios del comercio y capitán negto de la guetra, según la religión maya. Acaso su centro devocional haya estado en Copán, no lejano de Esquipulas.

7 Carlos Navarrete, Ricardo Toledo Palomo y el suscrito, han publicado artículos sobre este tema, pero los dos primeros tienen en preparación extensas obras al respecto.

${ }^{8}$ En Juan Paz Solórzano, Historia del Señor Crucificado de Esquipulas, de su santua. rio; romerías, etc., Guatemala, Imprenta Arenales e Hijos, 1914, pp. 7-8.

Ba En Granada, Nicaragua, verbigracia, hubo una iglesia de esa advocación que debió fundarse en la segunda mitad del siglo XVIII y que fue destruida por los filibusteros de William Walker en 1856. Véase Estampas de Granada y sus 450 años de fundación de Alejandro Barberena Pérez, Managua, Imprenta Nacional, 1974, p. 322. 
Aún ahora concurren para sus festividades, el 15 de enero y durante la Semana Santa, gran cantidad de peregrinos de El Salvador, Honduras y Oaxaca y Chiapas en México, además de numerosos guatemaltecos, convirtiéndola en el gran centro devocional del sur de lo que había sido Mesoamérica. El investigador guatemalteco Carlos Navarrete ha detectado la presencia de esta devoción en numerosas esculturas de este Cristo Negro, en poblaciones estratétigas en relación a los viejos caminos prehispánicos que siguieron siendo enclaves comerciales en la época colonial. ${ }^{8 b i s}$ En todo caso, lo interesante es que según este investigador estaría vinculada su presencia a Ek-Chuah, el dios del comercio entre los mayas antiguos, a quien se le asociaba al color negro en la iconografía precolombina.

Entre las principales esculturas coloniales del aludido Cristo, que se encuentra en la parte meridional de México, en Chiapas, podríamos citar la de San Juan Zinacantán, así como el famoso Cristo negro de Tila, en el Norte del estado, cuya aparición se supone haber ocurrido en el siglo XVII con carácter milagroso y en una cueva de tipo sagrado para los indígenas mayas. ${ }^{9}$ Siguiendo hacia el norte, en Oaxaca, hemos localizado esculturas en Xoxotitlán, Santa María del Tule y Mitla, así como en el famoso santuario del Cristo de Tlacolula, todos ellos en las inmediaciones de la vieja ciudad de Antequera del Valle de Oaxaca. ${ }^{10}$ En el aludido santuario de Tlacolula hemos podido identificar un Cristo de Esquipulas cerca del púlpito, que es guatemalteco, como muy probablemente lo son dos esculturas de tamaño natural de la Virgen María y San Juan que opinamos deben ser originales del siglo XVII o principios del XVIII." Según Navarrete, el Cristo de Tlacolula era inicialmente negro y fue blanqueado en el siglo pasado.

En Yucatán, podríamos citar las imágenes Ixmul y Junuhmá; a esta última se le traslada a hacer una visita al puerto de Sisal, a donde se le lleva

8bis Datos tomados de sus libros inéditos Esquipulas: aventuras y andanzas de un Cristo negro y Golontón y Joloniel, dos cuevas mayas del norte de Cbiapas. El autor tiene más de medio centenat de cristos negros localizados.

- Según el autor antes citado, existen en México templos dedicados a Esquipulas en Campeche, Santa Catalina de la Frailesca (Chiapas), Totomilco de Guadalajara, y hay imágenes en San Juan Bautista, Tabasco, además de Tila. Navarrete, sin embargo, tiene localizados una gran cantidad de lugares en los que se tinde culto al Crísto de Esquipulas, varios de los cuales incluimos gracias a su colaboración Vid Paz Solótzano, op cit., p. 48.

10 Estamos convencidos de que en muchas poblaciones de Oaxaca, tanto en sus iglesias como en casas particulares, existen esculturas, pinturas y estampas del Cristo de Esquipulas, llegadas mediante comercio o traídas directamente por los peregrinos que viajaban a Esquipulas.

11 En Tlacolula se le rinde culto a un Cristo negro que quizás esté relacionado, asimismo, con el Cristo negıo de Esquipulas, posibilidad que valdría la pena investigar. 
en una procesión marítima compuesta de numerosas embarcaciones. Mucho más al norte, en Guanajuato, existe en Moroleón uno de dimensiones menores, pues casi todas las anteriores esculturas son de tamaño natural, y que tiene la particularidad de tener un corazón movible mediante un sistema pendular que lo hace muy impresionante. El de la capilla del Señor de Durango se transformó de Cristo, propiamente dicho, en Niño de Esquipulas, mediante una curiosa metamorfosis. Igualmente lo hay en la Iglesia de San José, en la ciudad de Aguascalientes. También se ha documentado su presencia en Imuris, Sonora, y es más conocido todavía su santuario en Estados Unidos de Norteamérica, en Chimayó, Nuevo México, a donde fue llevado a mediados del siglo pasado por un emigrante mexicano. En la difusión del culto esquipulense hacia el norte, jugó un papel importante el franciscano fray Antonio Margil de Jesús, quien lo llevó personalmente, como ejemplo, al convento de Guadalupe, Zacatecas, a principios del siglo XVIII.

Iconográficamente, se debe mencionar que aunque el Cristo de Esquipulas haya sido hecho al final del siglo XVI, ya dentro de una corriente completamente renacentista, algunos autores han señalado su posible origen precolombino, entre otras razones por su color moreno oscuro. Como conjunto, sin embargo, se le añadieron en pleno siglo XVIII las figuras de la Virgen María, María Magdalena y San Juan, con características definidamente barrocas, observándose que dichas adiciones también se producen en muchas de las imágenes que se encuentran en la Nueva España, como podríamos citar las previamente aludidas de Santa María del Tule y Mitla, lo cual, por otra parte, no es de extrañar, por las frecuentes peregrinaciones que aún en la actualidad se efectúan procedentes de diversas poblaciones de Oaxaca y Chiapas a Esquipulas, en el oriente guatemalteco. ${ }^{12}$

El otro culto de carácter popular que parece haber surgido en el altiplan no central de Guatemala, hacia mediados del siglo XVII, es el del Rey San Pascual, y que no es sino el culto a la muerte, que se ha confundido con el rendido al santo franciscano San Pascual Bailón (1540-92), el cual fue beatificado en 1618 , habilitándole, en consecuencia, para ser venerado, con lo que se desarrolla su popularidad, ayudada por la orden franciscana. ${ }^{13}$ Con la peste provocada por la enfermedad llamada por los indígenas cak-

\footnotetext{
12 Como decíamos antes, imágenes particularmente de tamaño pequeño de procedencia guatemalteca, pero sobre todo de Esquipulas, deben haber viajado y viajan aún en la actualidad, de Guatemala a Chiapas y Oaxaca.

${ }^{13}$ Luis Luján Muñoz, "La devoción popular del Rey San Pascual" en Folklore de Gua. temala. No. 3. Guatemala, Departamento de Arte Folklóriço Nacional, Dirección General de Bellas Artes, 1967, pp. 22-54.
} 
chiqueles cumatz (culebra,) que algunos han identificado con el tifus exantemático, se crean las condiciones necesarias, en 1650, para mezclar el culto a San Pascual Bailón con el de la muerte. Dicha devoción parece haber surgido en la población de San Andrés Dean, ahora Ceballos, en las inmediaciones de la ciudad de Santiago de Guatemala, habiéndose despertado un entusiasmo tal por rendirle culto a la armazón de la muerte, vale decir el esqueleto, que las autoridades se vieron obligadas a intervenir ordenando la destrucción de tales imágenas, acerca de lo cual hemos pormenorizado en otro trabajo nuestro, al que remitimos al lector interesado. ${ }^{14}$

Lo curioso en este caso, que no dudamos en calificar de sincretismo religioso, es que existen antecedentes, en cuanto al culto de la muerte, tanto en la tradición prehispánica como en la hispánica, acerca de lo cual tampoco insistimos. Pero sí nos interesa mencionar que Navarrete ha encontrado referencias a cultos idolástricos de la muerte, de origen precolombino, que hicieron eclosión a partir de la peste aludida, amparándose en el nuevo culto a San Pascual Bailón, como patrón de la buena muerte, so capa de su catolicismo, pero su repentina popularidad puso sobre aviso a las autoridades españolas, que trataron de cortar de tajo esta devoción. ${ }^{15}$

En todo caso, creo que podemos pensar en una nueva popularidad del Rey San Pascual a raíz de la independencia, cuando se ablanda bastante la rigidez de las autoridades eclesiásticas, lo cual acaso podamos relacionar con la presencia del cólera morbus en estas regiones, que tiene lugar hacia 1836, año en que parece surgir dicho culto en San Juan Olintepeque, Quetzaltenango, $y$ en San Bernardino Patzún, Chimaltenango. Muy probablemente de estos focos la devoción se pasó a Chiapas, en donde en Tuxtla se constituye una hermandad dedicada a San Pascual Rey que ha devenido en San Pascualito, y en donde se construyó un nuevo templo dedicado a su devoción, que se concluyó en 1959 y fue entregado a la Iglesia católica.

Lo curioso es observar la difusión de este culto, procedente de Guatemala y que va a producir una variante iconográfica con respecto a la muerte que se difundió por un territorio relativamente grande pero que en la actualidad parece haber quedado circunscrito a San Juan Olintepeque y Tuxtla Gutiérrez, pero que necesariamente debió tener muchas imágenes

\footnotetext{
14 Francisco Antonio Fuentes y Guzmán, en la Recordación florida, dice que desde 1650, por lo menos, había en el desfile procesional del Viernes Santo, la carreta de la muerte, lo que siguió sucediendo hasta por lo menos 1920 . Véase Luján Muñoz, op. cit.

${ }_{15}$ Vid. Carlos Navarrete, San Pascualito Rey y el culto a la muerte en Chiapas, México, Universidad Nacional Autónoma de México, 1983. Allí se puede obtener amplia información sobre su culto en Chiapas con sus antecedentes.
} 
de culto, tanto en Chiapas como en Guatemala, las cuales se podrían localizar investigando concienzudamente.

\section{Características de la escultura barroca guatemalteca}

Veamos ahora el porqué de la fama de esta escultura que se producía en Guatemala y que con tanto entusiasmo se importaba de la Nueva España, para lo cual intentaremos caracterizarla, analizar las técnicas utilizadas para su realización y su evolución estilística.

Indicaremos, para principiar, que resulta prácticamente imposible hacer la diferenciación entre el trabajo de lo que sería propiamente la talla escultórica, del estofado y encarnado, que podían ser encargados a los especialistas. No es raro que en los contratos se estipulara que una obra sería entregada "en blanco", para luego ser estofada por otro artista, e inclusive encarnada por otro. De esta manera, había pocas ocasiones en las que el escultor trabajaba de principio a fin una escultura. Como quiera que sea, el hecho es que la mayor parte de las veces estos contratos se hacían de palabra y por tanto no constan documentalmente, lo que hace prevalecer el anonimato.

La técnica del estofado propiamente dicha -aunque en Guatemala, por lo general, al utilizarse este término se incluye todo el procedimiento habitual-consiste en imitar las telas bordadas. Ello se puede hacer utilizando una técnica doble, si se dejó el relieve en la talla y si no se logra mediante los drapeados trabajados a base de pintura. Los colores se debían preparar con tierras muy finas disueltas en agua, a lo que se le añade huevo batido con unas gotas de vinagre y tallos de higuera verde, según lo aconseja don Francisco Pacheco. ${ }^{16}$ Después, con un punzón de madera se dibuja sobre esta pintura y va apareciendo el dorado. Algunas veces, sin embargo, se utilizaba la pintura al óleo, así como también se aplicaban telas para las orlas para darles mayor realismo. Los encarnados se hacían a base de pintura al óleo, que podia ser pulimentada e incluso barnizada cuando generalmente es de influencia sevillana, se aplicaba en el primer caso una o dos manos de albayalde molido al agua con cola no muy fuérte.

Respecto de la importancia de los conceptos estéticos de quienes encargaban estas culturas a los artistas, haremos notar que normalmente el costo de la talla propiamente dicha era menor que el de la policromía que se le

${ }_{16}$ Citado por Martín Domingo Sánchez-Meza, Técnica de la escultura policromada graradina Victoria, Universidad de Granada, 1971. 
aplicaba; es decir, que se valoraba más el trabajo del encarnador, dorador o pintor que el del escultor. ${ }^{17}$

La técnica del estofado se caracteriza por una gran riqueza en la policromía que se pone sobre el dorado, para semejar brocados, sedas, bordados, etc., ricamente trabajados para dar todo el realismo de estos textiles, de manera que los elementos vegetales, como rameados, hojas y flores, resaltan maravillosamente sobre el rojo, azul, verde, blanco y negro, que a su vez está superpuesto al dorado que puede ir esgrafiado o resaltado a base de puntos, líneas y otros elementos y formas.

Dentro del realismo tan característico en el arte español, el uso de elementos como pestañas, ojos y lágrimas de cristal en las imágenes femeninas, se convierten en elementos típicos del barroco, pues en Guatemala parecen haberse comenzado a utilizar desde mediados del siglo XVII, precisamente coincidiendo con la introducción del barroquismo ${ }^{18}$ También se acostumbraron a incorporar, aunque mucho más raramente, piezas que simulaban la dentadura, así como en determinadas circunstancias también se emplearon cabelleras naturales, generalmente donadas por personas devotas.

Dentro del barroco escultórico guatemalteco se podrían notar dos etapas, una que deberíamos llamar barroco propiamente dicho, la cual duraría desde sus inicios hasta mediados del siglo XVIII, y una segunda etapa que podríamos denominar rococó, que se iniciaría desde mediados del siglo XVIII hasta la conclusión del mismo, e inclusive prolongándose hasta bien entrado el siglo XIX, según señalábamos antes.

Las características diferenciales entre la primera y la segunda etapa consistirían fundamentalmente en las actitudes un poco más teatrales de las imágenes en la última fase, así como una mayor presencia del dorado, ya que la decoración que iba sobre éste pierde un poco de finura al hacerse los rameados y el resto de la decoración vegetal más grandes. Sobresalen como temas fundamentales en el rococó la profusión de Calvarios, primordialmente Vírgenes de Dolores, cuyas vestiduras se hacen más ampulosas y abullonadas que en el periodo anterior, así como arcángeles en actitudes que parecen teatrales o de danza, y que incluso parecen llevar pelucas o peinados a la manera cortesana europea, también muestran cierta tendencia a la obesidad, que era tan del gusto de la época.

17 Dentro de esta diferenciación de trabajo, en la que los doradores o estofadores etan muchas veces conocidos pintores profesionales, resulta interesante observat que muchas veces se pagaba más por el trabajo de policromía que por el de la talla.

${ }^{18}$ Esta información la hemos obtenido por las observaciones tealizadas por nosotros en numerosas esculturas así como mediante entrevistas con imagineros contemporáneos. 
Trataremos ahora de caracterizar los rasgos primordiales de la escultura guatemalteca del periodo barroco. Primeramente vale la pena señalar la persistencia de ciertos elementos renacentistas en las actitudes de determinadas esculturas y en la técnica misma del policromado. Asimismo, el manierismo se nota en el uso de la forma serpentinata, así como la exageración en las dimensiones de manos y pies, los que aparecen con los dedos muy separados entre sí y con las articulaciones también muy definidas. En ambos casos, es muy probable que la influencia haya venido y se haya conservado por medio de los grabados.

Como ya dijimos, el dominio del oficio adquirido durante la etapa renacentista-manierista, que según nuestra cronología va de 1558 a 1676 , llega a su perfección en la época barroca. Lo anterior coincide con la toma de conciencia de los criollos y mestizos, que se permiten perfilar expresiones estéticas distintas a las de la metrópoli, aunque éstos sean matices dentro de los conceptos generales. ${ }^{19} \mathrm{~A}$ lo anterior, debemos añadir una situación económica relativamente favorable que hizo posible emprender una serie de construcciones que requirieron del adorno interior: retablos, esculturas, pinturas, mobiliario, platería y todas las demás manifestaciones artísticas acordemente barrocas. Por ello creemos que entre 1717 y1773, es decir, entre los terremotos de San Miguel y los de Santa Marta, es cuando se llega al mayor esplendor de la escultura barroca, porque fue necesario tallar, dorar y encarnar todas estas esculturas, que servirían para llenar esa inmensa cantidad de edificaciones.

Desgraciadamente para la historia del arte y para quienes nos interesamos en dicha especialidad, el anonimato prevalece. De pocas de las más importantes imágenes se puede saber el nombre de sus autores. Pese a la laboriosa labor investigativa del Dr. Heinrich Berlín, por ejemplo, poco se ha podido adelantar en esto; no así en el caso de arquitectos de retablos o de alarifes. En lo que se refiere a la escultura, reiteramos, la inmensa mayoría de las imágenes de culto doméstico, y aun la inmensa mayoría de las de culto público de las iglesias, no se sabe el nombre de los escultores, como no sean los casos, v. g., de Mateo de Zúníiga, autor de Jesús Nazareno de la Merced, ei San Sebastián y San Francisco de Paula de la catedral metropolitana, ambas de Juan de Chávez, así como el San José y el Niño

\footnotetext{
19 Los grandes periodos de la escultura guatemalteca que hemos considerado son los siguientes: a) Periodo de Post-conquista (1524-1558); b) Periodo renacentista-manierista (1558-1676); c) Periodo barroco (1676-1797); d) Periodo neoclásico (1797) hasta principios del siglo $\mathrm{XX}$ ). Consúltese Luis Luján Muñoz, Rasgos distintivos del manierismo en la escultura del Reino de Guatemala. México, Instituto de Investigaciones Estéticas de la UNAM, 1976. Por ello estimamos que la cronología que formula el Padre Antonio Gallo S. J. es muy discutible.
} 
de la iglesia de Santo Domingo, atribuida tradicionalmente a Alonso de la Paz. ${ }^{20}$

Acerca de la producción que nos ocupa, la escultura, nos encontramos en una situación en la que había gran unidad de criterio, ya que tanto los funcionarios eclesiásticos como los particulares que encargaban las esculturas para las iglesias, oratorios privados o casas habitación, como los escultores y artistas que las esculpían y policromaban y los feligreses que iban a esas iglesias y oratorios, estaban convencidos de las excelencias de estas expresiones artísticas e incluso de las pesibilidades milagrosas que algunas de ellas habían tenido o podían tener. Se daba pues una situación plena de unidad y comprensión como probablemente nunca después de la época barroca ha existido. Posiblemente de allí parta la idea del valor y la fama que esta escultura policromada tiene en el ámbito de Centroamérica y México, que era a donde se enviaban las esculturas procedentes de Santiago de Guatemala. Quizás por ello también durante todo el siglo XIX y parte de éste, todavía existían artistas que conservaban la tradición de hacer las tallas y policromarlas, pese a la fuerza con que trató de imponerse el neoclasicismo y a las corrientes del arte contemporáneo, así como el pensamiento antirreligioso tan característico de la época liberal decimonónica. ${ }^{21}$

Finalmente, debemos de subrayar que por razones obvias fueron las esculturas de media talla y las de pequeñas dimensiones, es decir, de culto doméstico, las que viajaron a la Nueva España y ahora viajan a México para las colecciones privadas. Se debe advertir que si el estofado y encarnado son finos, en general, en la escultura guatemalteca, más las han sobrepasado en excelencia, por su finura, las pequeñas tallas que adornarían dormitorios o capillas privadas.

\section{La escultura religiosa barroca guatemalteca vista contemporáneamente desde México}

Dice Heinrich Berlín que en México los cicerones de los museos con mucha frecuencia, cuando quieren enfatizar el valor de una escultura, dicen

${ }^{20}$ Gracias a las investigaciones del Dr. Heintich Berlín y a la publicación de su obra Historia de la imaginería colonial en Guatemala, Guatemala, Instituto de Antropología e Historia, 1952, se ha podido tener información fidedigna sobre la escultura y los escul-

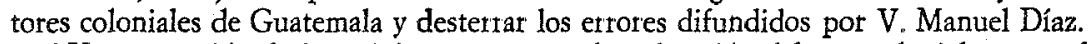

21 Una excepción decimonónica en cuanto a la valoración del arte colonial guatemalteco es José Martí, quien en su pequeño y bello libro Guatemala, se expresa encomiásticamente no solo de los artistas coloniales, sino también de los contempotáneos, como Julián Perales, que seguía tallando Cristos 
que es de origen guatemalteco. ${ }^{22}$ Esto es muy cierto, y viene a ser un testimonio de que los mexicanos siguen siendo los grandes valoradores de la escultura religiosa guatemalteca, de acuerdo con una tradición que arranca desde mediados del siglo XVI, cuando el obispo de Yucatán, el conocido fray Diego de Landa, hace viaje desde Mérida para obtener algunas esculturas religiosas en la ciudad de Santiago de Guatemala, entre ellas la famosa Virgen de Izmal. Dicho viaje tuvo lugar hacia 1560, según fray Francisco Vázquez y Francisco Florencia. S. J.23

Se sabe, también, de otra escultura del siglo XVI de casi seguro origen guatemalteco, la Virgen de la Merced, ahora en la iglesia de Belén de la ciudad de México, adjudicada a los mercedarios a principios del siglo XX. Se relata que fray Francisco de Vera vio, en 1595, durante su asistencia a un capítulo provincial de la orden de la Merced en Santiago de Guatemala, dos imágenes de esa Virgen y decidió llevar una a México, al convento grande mercedario. La escultura, trabajada en cedro y estofada, mide 1.26 m. y todavía tiene ciertas reminiscencias góticas en su rostro. Tanto Gonzalo Obregón como Aline Ussel piensan que es con certeza guatemalteca. ${ }^{24}$

Debemos admitir que no quedan muchos ejemplos de esculturas renacentistas ni manieristas en Guatemala. La inmensa mayoría de ejemplos de la escultura colonial son de tipo barroco, aunque en ellas se mantenga la tradición de usar algunos elementos tanto del Renacimiento, por ejemplo la decoración del estofado, como manieristas, como son los casos ya señalados de las proporciones elongadas de manos y pies. ${ }^{25}$ De cualquier manera, debemos manifestar nuestra admiración por la enorme profusión y calidad de la escultura barroca guatemalteca.

Como antecedente acerca del prestigio de que gozaba la escultura colonial guatemalteca en México, citaremos a José Ignacio Vallejo (1718-80), mexicano perteneciente a la Compañía de Jesús, quien fuera de los exiliados de Guatemala en 1767 y publicara varias obras en Italia, en una de las cuales, al referirse a las iglesias de la ciudad de Guatemala dice:

\section{Berlin, op. cis, p. 9.}

${ }^{23}$ Fray Francisco Vázquez, Historia de la Provincia del Santisimo Nombre de Jestis de Guatemala, Guatemala, Sociedad de Geografía e Historia, citado por Francisco Florencia S. J., Zodíaco mariano, México, Nueva Impreta del Antiguo Colegio de San Ildefonso, 1755, p. 251.

${ }^{24}$ Aline C. Ussel, Esculturas de la Virgen Maria en la Nueva España, México, Instituto Nacional de Antropología e Historia, 1975, pp. 52-53.

${ }^{25}$ Luis Luján Muñoz, "La escultura barroca en el Reino de Guatemala". Ponencia en el Simposio sobte el Bartoco Latinoamericano. Roma, Instituto Italo Latinoamericano y UNESCO, 1980. 
XI

Sus otros Templos Grandeza, Donde tanto Oro, que brilla, Dió la Octava Maravilla, Que echó el Resto a la belleza: $\mathrm{O}$ que adornos ¡Que Limpieza!

No estoi para retratarlos;

Más para medio pintarlos

Diré, que bajan, al verlos

Los Angeles a varrerlos, Las Estrellas a adornarlos
XII

También se levanta erguido Del dulce JOSEPH un Templo, En que yo a ratos contemplo, Primor de Vulto esculpido:

Pero que Templos no han sido Allí colosos ufanos;

Palacios, que Americanos

Erigen con bizarría,

Por tener de noche, i día

El Corazón en las Manos

Esta alusión a una escultura de San José, la vemos ampliada en la mención que hace, así como los nombres de unos artistas, los primeros escultores y los segundos encarnadores, en otra de sus obras. Veamos:

Las estatuas del Santísimo patriarca (San José) que allí (en Guatemala) se hacían y se veneraban eran por ser multitud innumerables, y todas según las medidas del arte, que perfectamente poseían en estos últimos templos los célebres maestros Blas Bodega y Matías España.

... La encarnación se la daban a estas estatuas, que por lo común eran de finísimo cedro, los diestros oficiales Carlos Bolaños, Joseph Guzmán y Galeano Guzmán, con tal acierto que estas obras de sus manos eran tan pretendidas por toda aquella América, que apenas podín los artífices satisfacer los deseos de los pretendientes.

Seguramente se refería a la Nueva España y al Reino de Guatemala, cuando hablaba de toda aquella América desde los Estados Pontificios, concepto que es interesante subrayar porque parece ser una constante entre los jesuitas expulsos, la exaltación de lo hispanoamericano. Igual cosa sucede con una carta que que Antonio López de Priego, otro exiliado, dirigía desde Bolonia, el 1 de octubre de 1785, a su hermana religiosa y en la que afirma ". . . las estatuas de Guatemala no las igualan aqui"..

Resulta difícil, al referirnos ahora al barroco éscultórico, señalar las diferencias dentro del propio estilo que se da entre la segunda mitad del siglo

${ }^{26}$ Luis Luján Muñoz, "Una desconocida descripción poética de la ciudad de Guatemaia, en el siglo XVIII, hecha por el jesuita José Manuel Vallejo" en Anales de la Academia de Geografia e Historia. Tomo LIII (enero-dimiembre, 1980) Guatemala, Serviprensa Centroameticana, 1980, pp. 137-58. La segunda cita la tomamos de Ennesto Chinchilla Aguilar, Historia del arte en Guatemala. 1524-1962. Guatemala, Editorial José de Pineda Ibarra, 1963, p. 99. Infortunadamente no se dice de que obra de Vallejo fue tomada la cita.

26bis En Tesores documentales de México. Siglo XVIII. Compilación por Mariano Cuevas, México, Editorial Galatea, 1944, p. 129" 
XVII y el siglo XVIII, en que se nota una influencia rococó. ${ }^{27}$ En todo caso, no siendo éste el objeto de nuestro trabajo, reiteraremos únicamente que tenemos la impresión de que la mayoría de las esculturas guatemaltecas que se encuentran en México proceden de finales del siglo XVII, del XVIII y por lo menos del primer tercio del XIX.

Naturalmente, los ejemplos que aquí citaremos son pocos y acaso de cierta notoriedad, porque están respaldados por alguna fuente documental, la observación directa nuestra, o la referencia de algún especialista mexicano, que generosamente nos ha proporcionado su punto de vista. Empero, estamos convencidos que una concienzuda investigación tanto documental como visual, en iglesias, museos o colecciones particulares, daría una cifra bastante alta. Al propio tiempo, quizás daría ocasión para poder negar el origen guatemalteco de otras esculturas a las que se les ha atribuido dicha procedencia con el simple afán de otorgarles mayor importancia devocional $o$ artística.

Previamente pasaremos a mencionar juicios sobre la escultura colonial guatemalteca, emitidos por algunos historiadores del arte mexicano.

A principios de este siglo, pero haciendo referencia a acontecimientos de mediados del anterior, nos encontramos el interesante testimonio de don Antonio García Cubas, quien recordaba al describir algunos de los actos religiosos de la Semana Santa:

El Calvario del Padre Picaso llamaba la atención no solamente por las buenas esculturas debidas al cincel de nuestros hermanos los guatemaltecos..$^{28}$

Este impresionante espectáculo se montaba frente a la iglesia de la Merced.

El prematuramente fallecido Salvador Toscano, quien estuvo en Guatemala hacia 1939, publicó un interesante artículo titulado "La escultura colonial en Guatemala" que constituye el primer intento de revaloración de esta expresión estética en el medio cultural mexicano. ${ }^{29}$

La escultura colonial en Guatemala, como en el resto de América, es de carácter distintivamente religioso. Nacida a finales del siglo XVI, alcanza sus formas maduras en el XVII y principios del XVIII, iniciándose enton-

${ }^{27}$ De acuerdo con nuestro criterio, la cronología del rococó iría de 1776 a 1797.

27bis "Escultura religiosa guatemalteca", en Excélsior, México, D. F., 9 y 13 de octubre, 1929.

${ }^{28}$ Antonio García Cubas, El libro de mis recuerdos, México, Editorial Patria, 1969, p. 425. La primera edición es de 1904.

29 En Anales del Instituto de Investigaciones Estéticas. No. 5, México, UNAM, 1940, pp. 45-53. 
ces su agonía que continúa al través del siglo XIX, no sólo como una consecuencia de un proceso de académización de su arte, sino por la honda crisis que atravesó la inspiración católica que la abrumaba, después de las ideas 'ilustradas' y racionalistas hubieran de avanzar en todos los márgenes de la cultura. 30

Después de esta breve y juiciosa síntesis, menciona que la escultura guatemalteca está muy influida por la andaluza. Infortunadamente, Toscano, quien desenmascarara el mito creado por Víctor Miguel Díaz acerca del pintor guatemalteco inexistente, Francisco de Villalpando, cae en las redes de las mentiras de éste al tratar de la escultura guatemalteca, pues debió acudir a la única fuente informativa que por entonces existía. ${ }^{31}$

Entre las informaciones que aporta Toscano está su opinión acerca de que la Virgen de los Remedios de México “... guarda estrechas relaciones con otra pequeña imagen de Guatemala, que igualmente se considera como de las más primitivas, la Virgen del Socorro, actualmente en la catedral de Guatemala". Discrepamos, sin embargo, en las afirmaciones que hace acerca de que una imagen de Santiago Apóstol que se conserva en el Museo de Santiago de Antigua Guatemala, y que fuera traída por las huestes de. Pedro de Alvarado, pues estimamos que es de carácter popular, pero del siglo XVIII. Asimismo, discrepamos de su apresurada afirmación de que:

En Guatemala, por el contrario, el barroco no prosperó en los interiores. Apenas si hay retablos que valgan la pena de mencionarse como tales, así los de Santo Domingo y los del Carmen en la nueva Guatemala. Es que se quería que las imágenes quedasen aisladas para que nada distrajese la belleza de los Crucifijos, Dolorosas, Piedades, Cristos yacentes o Nazarenos. $\mathrm{Al}$ aislar la imagen de todo lo que le fuese accesorio, inconscientemente se eliminaban las bases que hubieran podida engendrar un arte barroco. ${ }^{32}$

Estimamos que el juicio anterior es un poco apresurado, toda vez que en la actual capital de Guatemala hay una gran cantidad de retablos, ciudad en donde el doctor Toscano parece no haber visitado ni la Merced, ni Santa Rosa, ni Capuchinas, iglesias en las que se conservan íntegros los retablos del siglo XVIII traídos de Antigua Guatemala. Pero aún se podrían enumerar muchísimos más de los altiplanos central y occidental, particularmente en las regiones de Chimaltenango, Sololá, Quetzaltenango y Totoni-

${ }^{30}$ Ibid, , p. 45.

${ }^{31}$ Efectivamente, las frecuentes contradicciones y las numerosas e intencionadas inexactitudes en las obras de Diaz han contribuido a poner en tela de duda y a marginar las informaciones sobre la escultura colonial en Guatemala.

32 Toscano, op. cit, p. 47. 
capán. Dice también Toscano que son escasos los ejemplos e influencia indígena en la escultura, toda vez que "ésta conservó la pureza castiza de Andalucía", lo que podría refutarse fácilmente recorriendo la enorme cantidad de poblaciones indígenas en las que tanto en las iglesias como en las sedes de las cofradías, se encuentran millares de esculturas de carácter popular.

Sin embargo, la fina percepción de Toscano le permitió ver los temas tratados por los escultores guatemaltecos, cuando escribe:

Con el siglo XVIII la escultura de Guatemala toma nuevos y peculiares caracteres. En primer término pierde el tamaño colosal que caracterizó a los usuales temas de la Pasión, a los Cristos en la Cruz, con la Cruz a cuestas, en la Caída, a las Dolorosas, a la Piedad o al Señor del Sepulcro; las proporciones naturales se pierden y aparecen aquellas esculturas de tamaño menor con que los anticuarios han querido peculiarizar a la escultura guatemalteca; además, cuando no se emplean paños y cabelleras -es común en Guatemala el empleo, según el Marqués Romero de Terreros, de ojo de vidrio y de pestañas de cabello- el policromado toma esos caracteres bizantinos de que la Nueva España tanto abusó..$^{33}$

En resumen, Toscano, como decíamos al principio, es el primero de los historiadores mexicanos que revaloran la escultura colonial guatemalteca, señalando como temas frecuentes de la estatuaria las Dolorosas y los con" juntos de la Piedad, por lo que se ve que visitó Quetzaltenango, Antigua Guatemala y algunas iglesias capitalinas. Asimismo, incluye también los Cristos yacentes o sepultados como motivos primordiales en la escultura guatemalteca. Unos años más tarde, Toscano vuelve a ocuparse del tema, al escribir sobre el arte de Chiapas, ${ }^{34}$ lo que trataremos en su oportunidad. Lamentamos que la prematura muerte de Toscano le hubiera impedido hacer un estudio posterior, más reposado y profundo de la escultura colo" nial guatemalteca.

Otra información que nos permite apreciar la gran demanda que tenían las esculturas guatemaltecas en México y en la propia capital es la referencia que se tiene del inventario hecho en la residencia palaciega del conde de San Bartolomé de Xala, en donde se puede ver que las hornacinas y las esculturas que en ella se encontraban habian sido enviadas de la ciudad de Santiago. Menciona Manuel Romero de Terretos, autor de dicho estudio, la presencia de esculturas grandes y pequeñas "... estofadas,

33 Ibid., p. 53.

${ }^{34}$ Salvador Toscano, "Chiapas: Su arte y su historia coloniales" en Anales del Instituto de Investigaciones Estéticas de la UNAM, México, 1942, pp. 27-43, (las ilustraciones van colocadas antes). 
de hechura de Guatemala, famosas desde aquellos tiempos".35 Dice el inventario:

... Una Ymagen de Ntra. Sra. de la Concepción, hechura de Guatemala, con corona de plata sobre dorada, vestido de Lama de Plata, Manto de Mué, guarnecido con punta; en noventa pesos... las Ymágenes de Cristo, la Ssma. Vírgen, San Juan y la Magdalena en el Monte Calvario, hechuras de Guatemala, estofadas, Ymagen de Sta. Gertrudiz, hechura de Guatemala, con vestido de Mué,... Una Ymagen de San Juan Nepomuceno, hechura de Guatemala, de más de una vara, ricamente vestido de género, ... ${ }^{36}$

Resulta curioso que no se mencionen en el inventario las esculturas de San José y la Virgen María, arrodilladas, que forman parte de un nacimiento, que son definitivamente guatemaltecas, según se observa en la figura 18 de dicha publicación; no así el Niño Dios, que probablemente era napolitano, según aparece en el mismo inventario. Es factible que algunas otras imágenes pudiesen haber sido guatemaltecas y no se hubiera anotado su procedencia. Pero el hecho que la santa patrona de la condesa fuera de origen guatemalteco, nos indica la estimación que se le tenía a estas obras.

Reafirma lo anterior la mención de Xavier Moyssén, quien demuestra que las personas que podían hacerlo solicitaban esculturas a Guatemala, como sucede en el caso del Marqués de Sierra Nevada, a quien en octubre de 1790 se le vende el conjunto de un Nacimiento guatemalteco; curiosamente, se asigna un mayor valor al estofado y encarnado, en relación a la escultura propiamente dicha, pues el costo era de $\$ 80$ por la escultura y de $\$ 100$ por lo otro, ambos trabajos realizados en la recién llamada Antigua Guatemala. ${ }^{37}$ Otro dato que nos hace pensar en la gran demanda que tenían los misterios o figuras del nacimiento guatemaltecos es la presencia, en el Museo de la Basílica de Guadalupe de la capital mexicana, de uno espléndido de dimensiones mayores de lo usual $(1.10 \mathrm{~m}$.), y de bellos colores, en los que predomina el rojo y el dorado, desgraciadamente con sus rostros

${ }^{35}$ Manuel Romero de Terreros, El arte en México durante el virreinato, México, Editotial Porrúa, S. A., 1951, p. 39. Afirma el autor que las esculturas de Guatemala eran excelentes y en muchos casos tenían cabellos y pestañas de verdad. Asimismo, en Una casa del siglo XVIII en México, México, Instituto de Investigaciones Estéticas de la UNAM, 1957, p. 57, tiene una brevísima opinión, muy similar, sobre las esculturas coloniales guatemaltecas.

${ }^{36}$ Romero de Terreros, op. cit, 1957, pp. 56-63.

${ }^{37}$ Xavier Moyssén, Estofados en la Nueva España, México, Ediciones de Arte COMERMEX, 1979, p. 22. 
retocados; la Virgen María tiene abundoso cabello suelto hasta la cintura, muy a la manera guatemalteca. ${ }^{33}$

Manuel González Galván es otro historiador del arte que ha dedicado juicios valiosos e interesantes a la escultura colonial guatemalteca, como consecuencia de un viaje que hiciera a nuestro país en $1958 .{ }^{39}$ Afirma González Galván que la escultura es evidentemente de mayor calidad que la pintura, siendo además más vigorosa y original y haber alcanzado un alto grado de perfección técnica. Dice:

- La escultura guatemalteca está muy cerca de lo mejor de la escuela española, especialmente sevillana, pero no deja de tener sus rasgos propios, que delatan cierta violencia o extremismo muy a lo americano. Esto es palpable en las expresiones de los rostros raramente serenos, pues se pasa del dolor macerado de los cristos y la angustia de las dolorosas, a iluminadas sonrisas de los San Antonios y San José, que juguetean con el Niño. Puede decirse que dos momentos claves en la vida de Cristo hacen la temática de la escultura centroamericana: una festiva, alegre y risueña, gira en torno al tema de Cristo niño: la otra, dramática y dolorida, en torno a la pasión y al Crucificado.40

Aporta este autor otras valiosas ideas acerca de la composición, al decir:

Compositivamente llama la atención la tendencia giratoria de los miembros de las figuras; los cuerpos no sacuden sus vestiduras como to he visto en México, sino que giran arremolinando sus ropajes, por lo que el torso, o al menos cabeza y brazos, suelen actuar en un plano que se desplaza hasta 60 grados en relación al plano en que actúan el resto de la figura, desde la cintura a los pies.

\section{$Y$ añade:}

Es notable también la rica policromía de los estofados, que al combinarse con gruesos, tersos y brillantes barnices, dan al terminado de toda la escultura un aspecto de porcelana, admirable y único. ${ }^{41}$

Concluye González Galván señalando el gusto por enriquecer la escultura policromada con abundancia de aditamentos de orfebrería e incluso

${ }^{38}$ Conocemos dos Misterios bastante similares a este de la Basílica de Guadalupe, particularmente en el estofado el primero, que perteneciera a la Catedral metropolitana de Guatemala, y otro que está en la iglesia conventual de Capuchinas, en la nueva Guatemala.

${ }^{39}$ Manuel González Galván, De Guatemala a Nicaragua, México, Instituto de Investigaciones Estéticas de la UNAM, 1968.

40 Ibid, p. 71 .

41 Ibid, p. 72 
piedras preciosas, entre los que podemos mencionar aureolas, halos, resplandores, potencias, dagas, espadas, etc., que por momentos le recuerdan la Edad Media o la oriental, dándole a la escultura guatemalteca un aspecto ritual muy peculiar.

Xavier Moyssén escribe, al referirse a las cuatro escuelas hispanoamericanas de la escultura colonial, que para él son la peruana, la quiteña, la guatemalteca y la novoespañola:

A la cabeza de las otras escuelas merece figurar la de la Capitanía General de Guatemlaa, por las proporciones que son tan peculiares de sus imágenes, y asimismo por el brillo de las encarnaciones y el colorido empleado, amén de la esmerada calidad de sus estofados. ${ }^{42}$

Manifiesta Moyssén más adelante:

La escultura guatemalteca a través de un eje que parte de Antigua y encuentra su centro y término en la ciudad de Oaxaca y Puebla, encontró enorme aceptación en el mundo novoespañol dieciochesco; nada improbable es el que haya ejercido aquí cierta influencia. La presencia de la imaginería en Guatemala se localiza básicamente en el elevado número de pequeñas piezas que al país llegaron, algunas existentes aún en iglesias y conventos de monjas y las más en poder de coleccionistas. Esas esculturas de reducidas dimensiones, representan graciosas versiones de la Virgen, según la advocación de que se trate. Los conjuntos de varias figuras son comunes, como los nacimientos y adoraciones, y no escasean los "calvarios"... La iconografía de santos, santas, mártires, arcángeles y ángeles es numerosa. Independientemente de la perfección lograda, en sus dimensiones, lo que asombra en estas imágenes, es la alta calidad artística que hay en las labores de sus estofados, los cuales parecen imitar los más fabulososo brocados, en los que el oro de los tejidos se combina admirablemente con la policromía de las sedas. Obras hay en las que la riqueza de los estofados compite ventajosamente con las elaboradas piezas de orfebrería que ostentan las imágenes. Del carácter de los estofados guatemaltecos, ofrecen un elocuente testimonio los ejemplos que en este libro se reproducen. ${ }^{43}$

Buena prueba de que las esculturas guatemaltecas del periodo barroco son muy abundantes en la misma capital de México, es la exhibición que con el nombre de Estofados en la Nueva España, se montata en 1979, y en cuyo catálogo Xavier Moyssén escribiera lo antes citado.

Por su parte, la historiadora Aline Ussel C. se refiere así a la escultura guatemalteca:

42 Moyssén, op. cit, pp 10-11.

4 Ibid, pp. 21-22. 


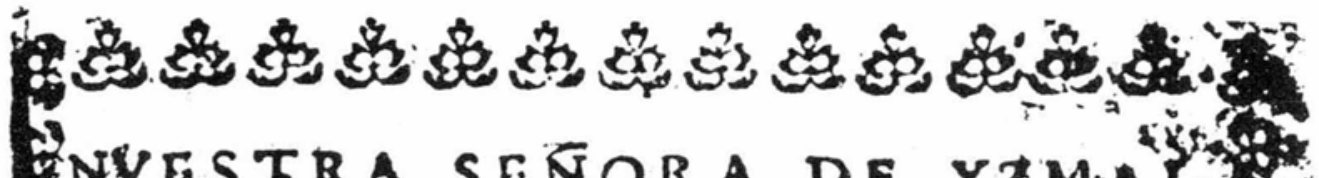
WHESTRA SENORA DE YZMALU

(3)

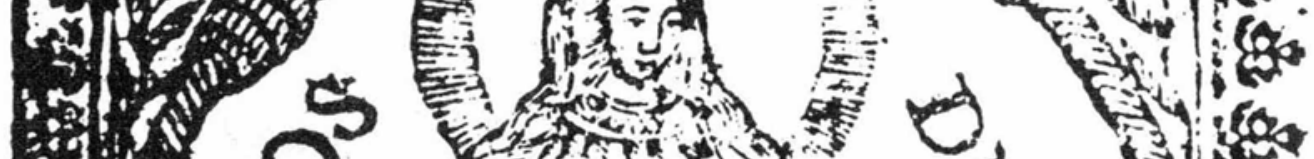

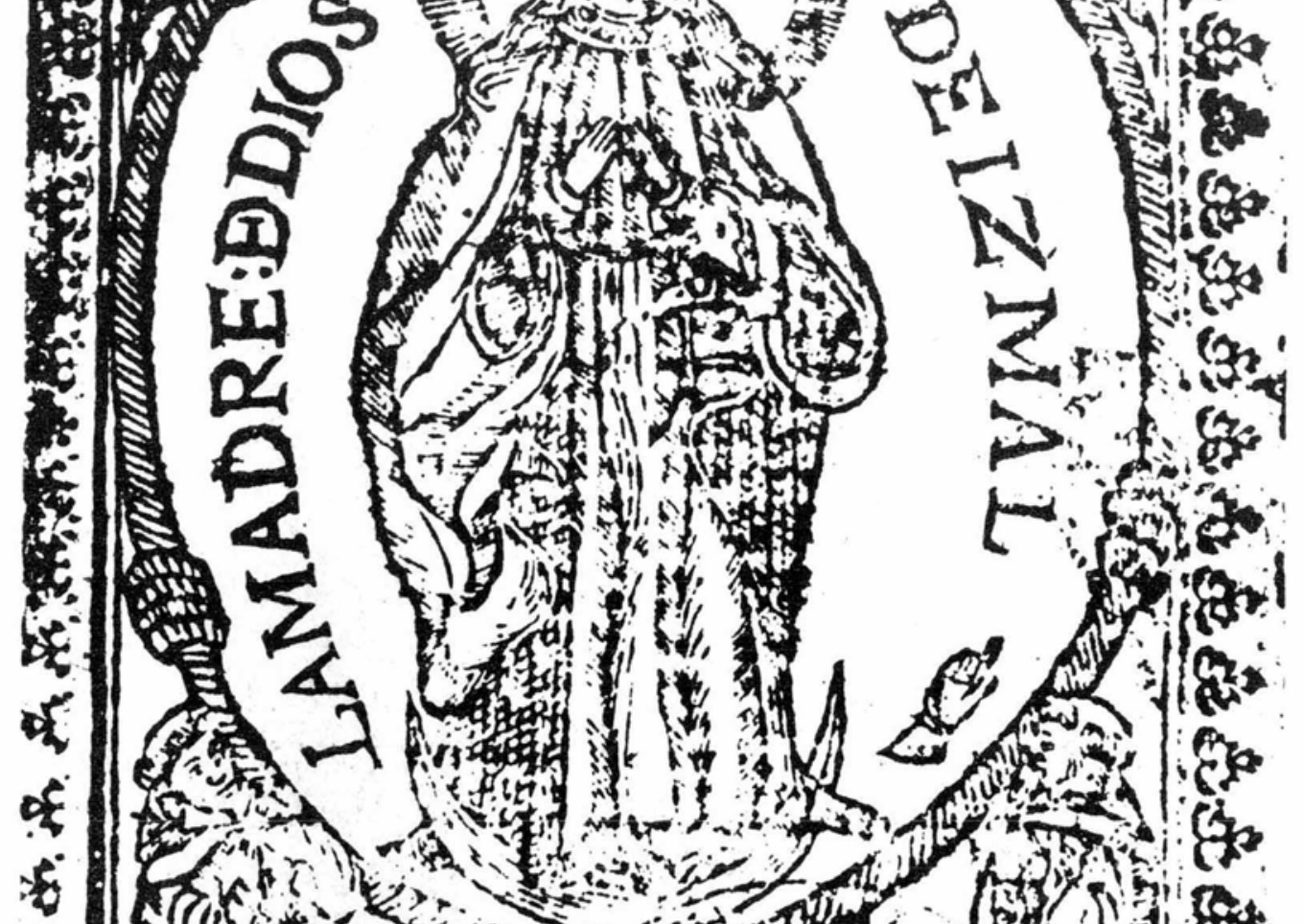

in ${ }_{1}($ (f)

6.

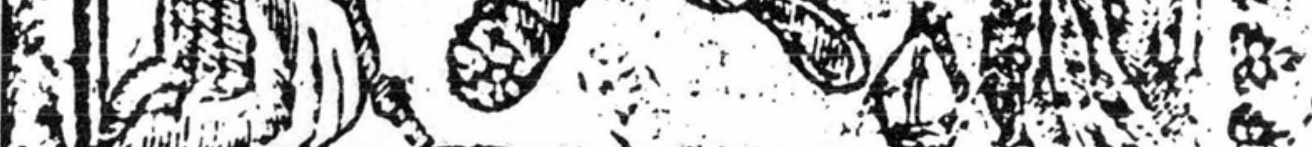

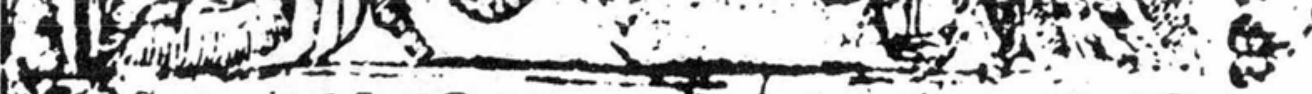

0.4

Figura 1. Virgen de Izamal, Yuc. Museo del Carmen. San Ángel. 
DOI: http://dx.doi.org/10.22201/iie.18703062e.1988.59.1407

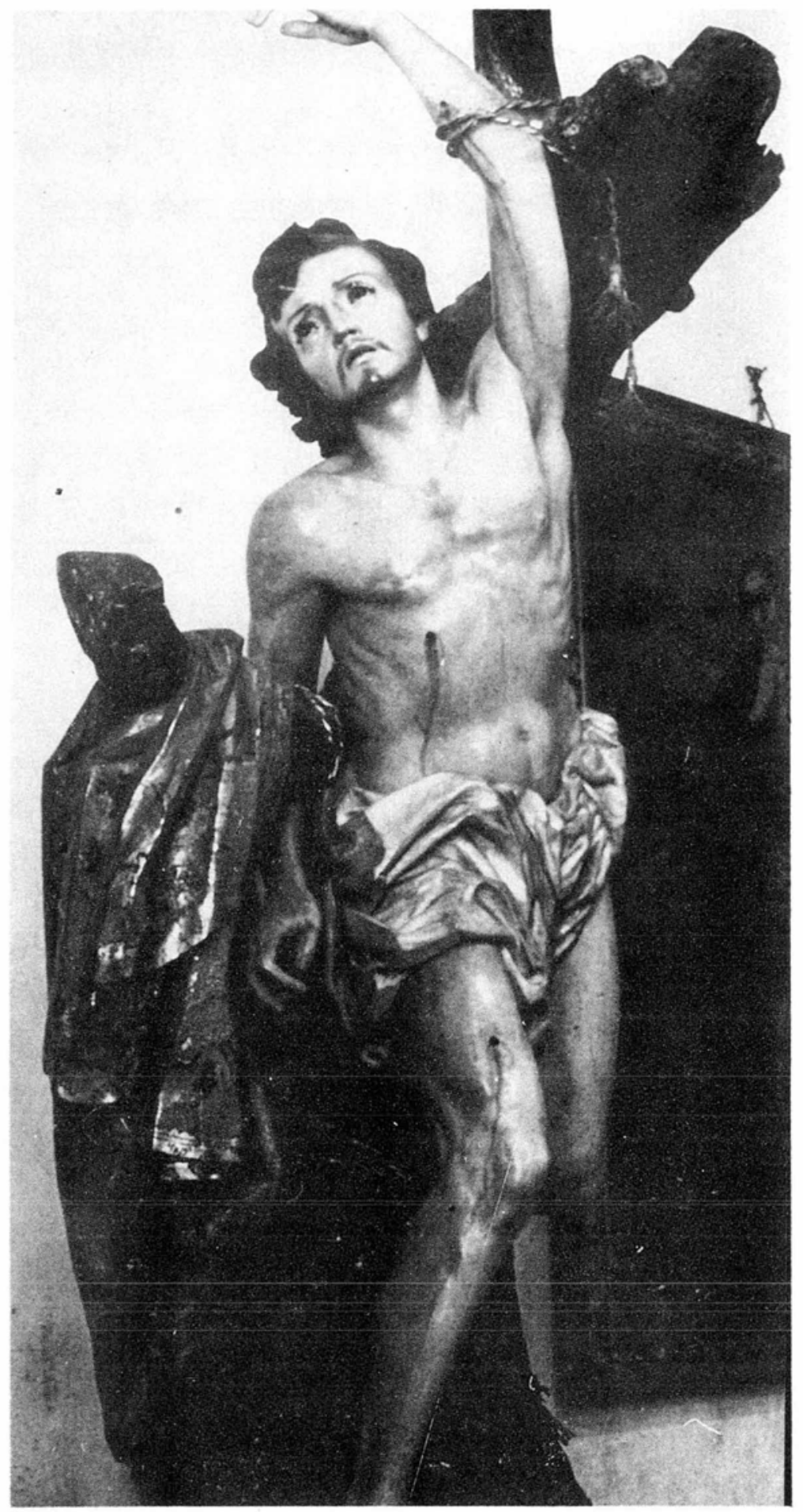

Figura 2. San Sebastián. Escultura en madera policromada de mediados del siglo XVIII atribuida a Juan de Chávez. Guatemala, Catedral Metropolitana. Fotografía del autor. 


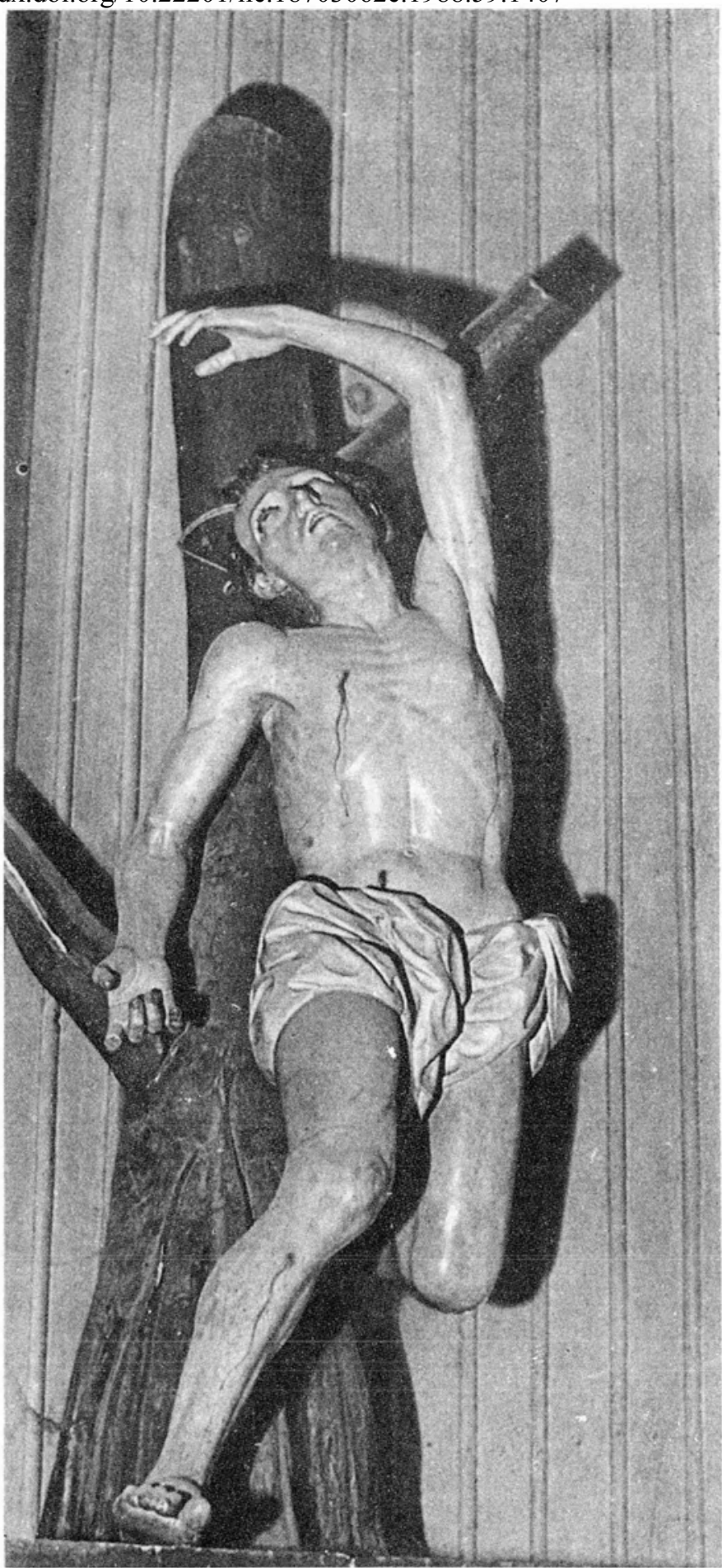

Figura 3. San Sebastián. Escultura en madera policromada de mediados del siglo XVIII, atribuible a Juan de Chávez. Iglesia del Carmen. San Cristóbal. Chiapas. Fotografía de Enrique Franco Torrijos. 


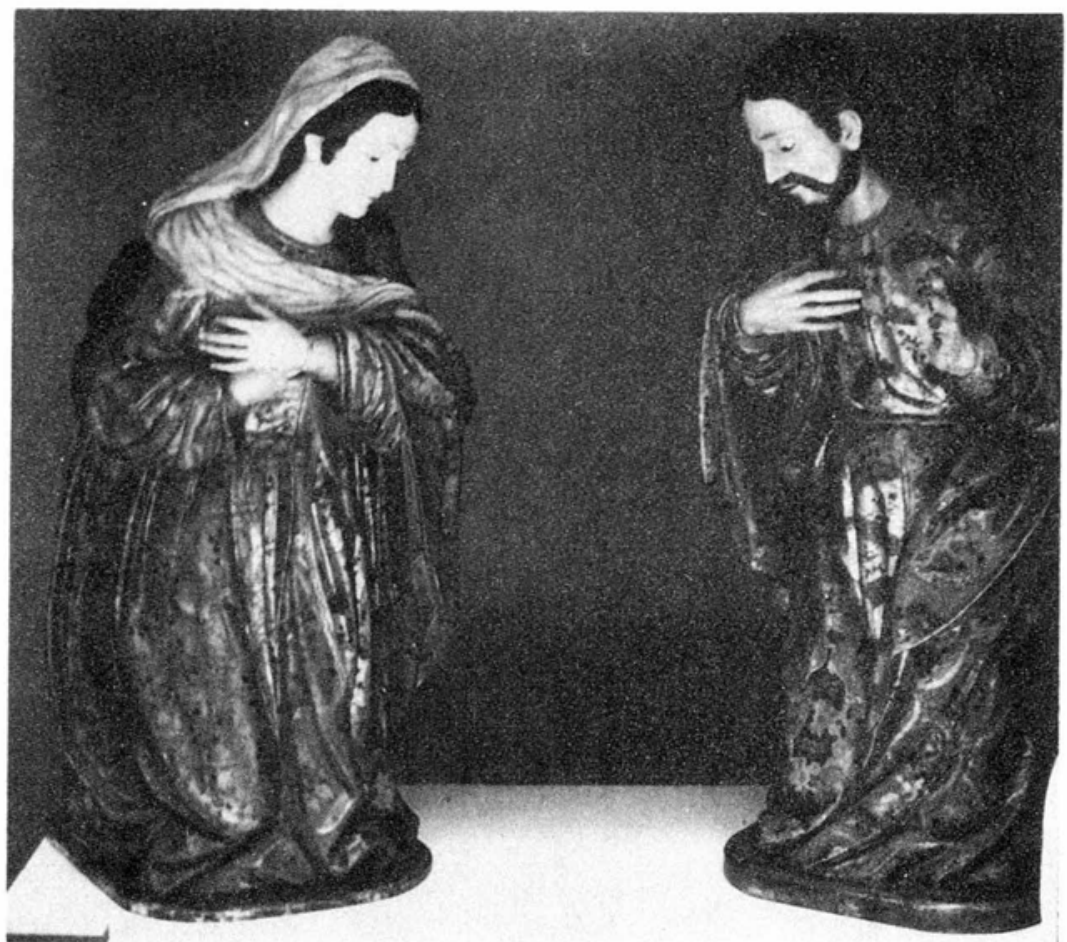

Figura 4. Virgen Maria y San José. Esculturas Guatemaltecas del siglo XVIII. Museo de la Basílica de Guadalupe. México, D.F.

Figura 5. Inmaculada Concepción. Siglo XVIII. Museo Nacional del Virreinato. Tepotzotlán, Méx.

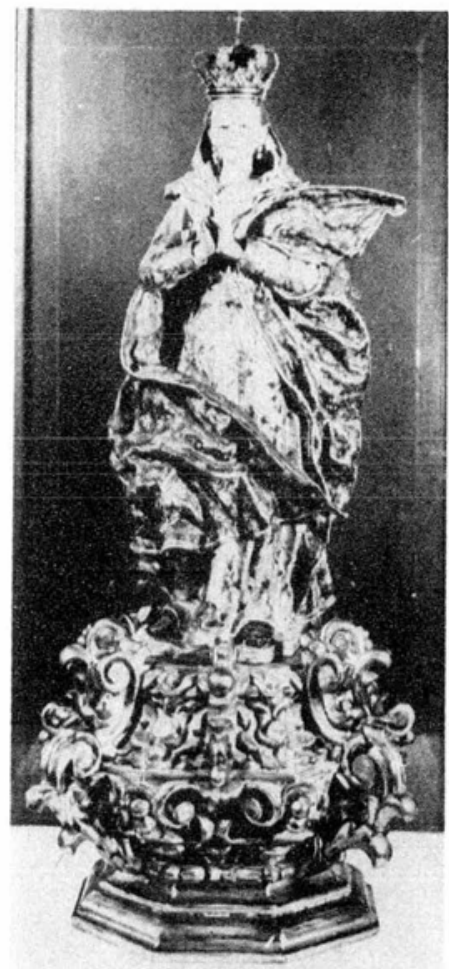


Existió una costumbre que atribuyó a Guatemala las mejores esculturas de la Nueva España. Tal aseveración no es exagerada, pues es exacto que surgió en Guatemala una corriente artística coherente, en que el anonimato fue menos frecuente y donde la técnica del estofado y la encarnación fueron excelente; mas esto no significa que las mejores tallas que existen en México hayan venido de este país; sin embargo, su influencia y la considerable importación son de tomarse en cuenta. ${ }^{44}$

Afirma la misma autora que la escultura en Guatemala estuvo menos influida por el arte indígena que en la Nueva España y que su proximidad estética con Andalucía es muy grande, impidiéndole alcanzar su libertad expresiva y una mejor definición propia; en esto discrepamos con Aline Ussel, porque creemos que si bien en la escultura culta guatemalteca no hubo influencia indígena, en cambio sí la hubo en la de carácter popular, que es muy interesante y valiosa, por cierto. Por otra parte, creemos que consiguió sus propios y definidos perfiles estilisticos, que hacen claramente diferenciable la escultura guatemalteca de la andaluza o la mexicana. ${ }^{45}$

\section{Esculturas coloniales guatemaltecas en Chiapas}

No deja de ser un tanto redundante el título de este apartado, toda vez que al ser Chiapas parte componente del Reino de Guatemala durante la época colonial, cualquier escultura de dicho periodo obviamente deberá ser de origen guatemalense, mientras no se pruebe lo contrario. Sin embargo, hemos decidido que así sea porque en la actualidad Chiapas forma parte de México, y también porque a causa de su lejanía con el centro, la región ha sido relativamente poco estudiada desde el punto de vista artístico, 10 cual se explica por lo dificultoso de sus vías de comunicación, que la hacían casi inaccesible desde el altiplano central mexicano, siendo mucho más sencillo y directo su vínculo con Guatemala que se conservó permanentemente hasta bien entrado este siglo. La comunicación aérea y la aper. tura de carreteras modernas hicieron que esta situación variara radicalmente hacia la década de los años cuarenta. Ello explica parcialmente, por ejemplo, que Chiapas esté casi ausente de la obra del ilustre Manuel Toussaint, de manera que no fue sino hasta el viaje del doctor Salvador Toscano que se inició el estudio y valoración de su arte colonial. A dicho estudio

44 Ussel, op. cit., p. 33.

${ }^{45}$ Luis Luján Muñoz, "Introduction" en Santos. Folk Sculpture from Guatemala. Los Angeles, Museum of Cultural History, University of California, Vol. 1, No. 10, 1980, pp. 2.6. 
siguieron los trabajos de Frans Blom, de Heinrich Berlín, de Jorge Olvera, y el importantísimo de nuestro maestro, el doctor Francisco de la Maza, y el cual utilizaremos primordialmente. ${ }^{46}$

Para Guatemala y su arte colonial, el estudio de Chiapas tiene una gran importancia, porque gran parte de sus realizaciones estéticas del siglo XVI se encuentran perdidas, pero en cambio existen abundantes y valiosos testimonios, particularmente de la arquitectura del siglo de la conquista. Además, necesariamente Chiapas, como sede diocesana, fue un importante foco cultural del Reino de Guatemala, parte fundamental, asimismo de la provincia religiosa dominica de San Vicente Ferrer, que funcionaba conjuntamente. Por otra parte, tiene valiosas realizaciones en los siglos XVII y particularmente en el XIX que complementan, necesariamente, el arte colonial de Guatemala.

$\mathrm{Al}$ referirnos concretamente al objeto de nuestro estudio, la escultura, vemos cómo en Chiapas se encuentran dos de las manifestaciones más antiguas del arte guatemalteco: relieves escultóricos en madera que formaron parte de retablos. Uno es el Cristo crucificado que actualmente se encuentra en el Museo Regional de Tuxtla Gutiérrez y que inicialmente parece haber pertenecido al Calvario de Chiapa de Corzo. Se trata de una composición en altorrelieve de sobria composición y figuras arcaizantes, particularmente el Cristo en la cruz, todavía muy medieval, a cuyo pie se ve una calavera de desproporcionado tamaño; la Virgen María y San Juan, flanqueando el motivo central que es Cristo, tienen un aspecto menos arcaizante, pero todo el conjunto en relieve tiene un regusto popular que dificulta tener la plena certeza de su primitivismo; también es interesante decir que se conservan rastros del estofado. ${ }^{47}$

El otro relieve, de mucho mayores dimensiones, es un Descendimiento de mucho más complicada composición y realización; el grupo de figuras, que son once en total, muestra una posible influencia de alguna estampa flamenca, que acaso sirvió de inspiración también al óleo que sobre el mismo tema pintara, en 1547, Pedro de Campaña (1503-ca. 1580) y que se encuentra en el Museo del Prado. Muy atinadamente señala Toscano que este relieve guarda una clara relación con el que se encuentra en el Museo Colonial de Antigua Guatemala, en el que aparecen unas santas clarisas, que

\footnotetext{
46 Francisco de la Maza, "Arte colonial en Chiapas" en Ateneo No 6, Tuxtla Gutiértez, mayo, 1956, pp. 59-122. Pese a este estudio y a los publicados sobre arquitectura por Sidney D. Markman, Chiapas todavía espera una gran obra de conjunto sobre su arte colonial, que deberá tomar muy en cuenta las artes plásticas de Guatemala y Centroamérica en general.

47 Según observación personal, este relieve tiene restos de policromía.
} 
él considera del siglo XVIII, pero que para nosotros tienen influencia manierista y son de la primera mitad del siglo XVII.

En todo caso, ambas obras señalan una clara línea evolutiva que nos induce a pensar en la posibilidad de que el relieve que está en Antigua haya formado parte de un inmenso retablo, probablemente dominico, que estuviera en la iglesia principal de dicha orden en Santiago de Guatemala, pues conocemos otro de las mismas dimensiones y características, pero únicamente con santos dominicos, lo cual nos indica que en el retablo original había probablemente por lo menos cuatro paneles con santos y santas de ambas órdenes mendicantes - la de Santo Domingo y la franciscana-, parte de los cuales desafortunadamente ha desaparecido. ${ }^{48}$

Aparte de los ejemplos ya mencionados, relacionados con el culto al Señor de Esquipulas y con el Rey San Pascual, hay esculturas dedicadas a otros santos que se encuentran en la antigua provincia guatemalteca de Chiapas, ahora estado de ese nombre.

Principiaremos con las referencias de Toscano, ampliadas con las informaciones de De la Maza y Navarrete, con algunas observaciones nuestras.

Toscano alude a que en la iglesia conventual de la Encarnación existe un Cristo en la cruz, muy probablemente de la escuela guatemalteca y una "preciosa y muy fina Santa Ana y la Virgen Niña", del siglo XVIII, y un San Sebastián que muy atinadamente relaciona con el de Juan de Chávez de la catedral de Guatemala: "... encontramos en ésta menos amanerar.iento y más dinamismo, expresado todo con fuerza dramática superior". Para nosotros, es evidente que es mejor la de la ciudad de Guatemala.

Según Navarrete, en la iglesia de San Sebastián en Comitán se encuentra una escultura que puede relacionarse con las dos anteriores, y que le parece de mejor factura que la de San Cristóbal. Dichas esculturas deberían ser de mediados del siglo XVIII, si el modelo original es el catedralicio, como es lo lógico pensar. De la Maza ve una posible reminiscencia prehispánica en el culto a este santo, vinculándolo con el sacrificio por flechamiento. ${ }^{19}$

Entre las ilustraciones de su trabajo, Toscano también incluye un Cristo caído, que se encuentra en la iglesia de San Nicolás en San Cristóbal Las Casas, así como un San Antonio de Padua que se encuentra en un retablo

${ }^{48}$ Por las dimensiones de los paneles es posible que hayan sido de alguna iglesia muy importante; dada la presencia de santos de las órdenes dominicana y franciscana, acaso hayan pertenecido a un gran retablo de alguna de dichas ótdenes. No perdemos lí esperanza que alguna vez pueda localizarse alguno de los otros relieves.

${ }^{49}$ De la Maza, op. cit., p. 97. El autor observa el parecido que tienen los San Sebastián de Juan de Chávez, con el de Francisco de Zumaya en la catedral de México, que es óleo, señalando atinadamente que ambos deben proceder de un grabado común. 
de la iglesia de Santo Domingo, también con el estofado y el encarnado característicamente guatemaltecos.

Desde luego, según indicamos antes, la abundante presencia de imágenes pictóricas y escultóricas del gran predicador dominico San Vicente Ferrer, con sus características alas y trompeta, se justifica plenamente por ser el patrono de la provincia religiosa dominicana de Guatemala y Chiapas.

Según de la Maza, en la iglesia conventual de Santo Domingo se encuentra un San Antonio estofado y encarnado, a lo que nosotros añadiríamos que sus técnicas escultóricas y de acabados son claramente guatemaltecas. Existe también un San José con el Niño en brazos, reclinado sobre su pecho, de estirpe claramente guatemalense en la técnica del tratamiento del cabello y barba del santo, así como su encarnado y estofado, y desde luego el Niño, que también es característicamente guatemalteco. Finalmente, cita de la Maza una escultura de la Trinidad "... por más que parezca guatemalteca ..." pero su belleza es tan especial que adquiere carácter universal como ejemplo de imaginería barroca. Continúa su descripción de la Maza:

Es una solemne Trinidad casi de tamaño natural. Está el padre, dignísimo anciano lleno de vigor, con tiara en la cabeza. Su mirada se pierde en el espacio, pero sus manos detienen amorosamente al Hijo, desclavado de la cruz, y por ello, muerto ya; es el Cristo un hermoso varón de pálido cuerpo adolescente que pliega y acomoda las rodillas del eterno. La diáfana limpieza de su cuerpo no se mancha de sangre como es costumbre en otras regiones de México, apenas si unos hilillos rojos interrumpen el nácar de su piel. El Espíritu Santo brota del seno del Padre posado en un haz de rayos ondulantes. Nubes y querubines en el escabel de esta Trinidad maravillosa. ${ }^{50}$

En el templo conventual de la Encarnación, que perteneciera a monjas carmelitas, alude, además del San Sebastián ya mencionado, a la escultura de Santa Ana enseñando a leer a la Virgen -y señalada por Toscano-, así como a un Cristo. De la Maza añade la presencia de un San Juan Nepomuceno, devoción que estuviera muy en boga en el Reino de Guatemala a fines del siglo XVIII, relacionado particularmente con la castidad de los religiosos. De la Catedral de Ciudad Real, incluye una fotografía en la que se ve un San Cristóbal (que para nosotros es característicamente guatemalteco) de la misma manera que un Cristo crucificado, que asimismo es de escuela antiguieña, como lo son dos imágenes de San José, una mediana y otra grande en sus tallas y otro San Juan Nepomuceno de transición al neoclásico.

50 Ibid., p. 87. G. Navarrete nos señala que en la población de Trinitaria de Guillén, cerca de la frontera de Guatemala, existe una escultura de dicha advocación bastante buena y de origen guatemalense. 
A las informaciones anteriores podemos añadir que en la iglesia de Santa Lucía pudimos observar un San José de buen estofe y procedencia guatemalteca. En la iglesia llamada Mexicanos hay una imagen de la Virgen de la Concepción, acaso de principios del siglo XVII, bien estofada y bien encarnada y que podría ser del mismo origen.

En la iglesia de la Caridad podemos observar una Virgen María que seguramente es guatemalteca, así como otra escultura de San Martín, de media talla, bastante buena. En la pequeña iglesia de San Nicolás hay una imagen del patrón, que preside su altar mayor, y un Cristo atado a la columna, ya observado por Toscano, que es muy claramente guatemalteco. En la iglesia de San Francisco, pudimos admirar una Virgen de la Concepción estofada y encarnada a la manera guatemalteca; a pesar de algunas buenas pinturas y retablos, salta a la vista la mucho mayor riqueza estética de la iglesia de la orden dominicana.

Con lo anterior terminamos con esta breve revisión de las iglesias de Ciudad Real de Chiapas, ahora San Cristóbal de Las Casas, respecto de la presencia de esculturas guatemaltecas en ella.

Tenemos un referencia para una población chiapaneca. Se trata de la Virgen con el Niño del retablo principal de la iglesia de Teopisca; debió de ser hecha en Guatemala, pues guarda semejanza con el tipo de rostro de la escuela guatemalense, si bien la cabeza es algo desproporcionada. Su gesto hierático pero elegante, nos haría situarla a principios del siglo XVII.

No está de más mencionar que en el aspecto general del arte de Chiapas se nota una influencia guatemalteca muy poderosa, pero también se admite una cierta influencia mexicana en la presencia de algunos retablos dorados con estípites a la manera churrigueresca, del cual apenas conocemos un ejemplo poco notorio por su composición, en la capilla de la Virgen del Rosario de la iglesia del Espíritu Santo de Quetzaltenango, ahora catedral. Es decir que desde Chiapas hasta los confines meridionales del Reino de Guatemala no se dieron dichos estípites churriguerescos, en la arquitectura propiamente dicha, y apenas se ven unos cuantos casos en la arquitectura de retablos, buscando Guatemala sus propias soluciones dentro de su rico y personal barroco.

\section{Imágenes escultóricas guatemaltecas en México}

Hechas las observaciones anteriores correspondientes al culto del Cristo de Esquipulas en Chiapas y el resto de Méxicơ, así como de la presencia de esculturas religiosas guatemaltecas en lo que fuera provincia de Ciudad Real, perteneciente al Reino de Guatemala, pasemos ahora a realizar una 
diseminadas en lo que fue verdaderamente el territorio de la Nueva Espa" breve revisión de las esculturas de origen guatemalteco que se encuentran ña, a sabiendas de que apenas se trata de un primer intento de situar esculturas guatemaltecas en México.

Comencemos, pues, a revisar lo concerniente a Oaxaca, en la inteligencia de que era una región muy vinculada a Guatemala por razones comerciales, ya que la ruta principal de comunicación entre la Nueva España y Guatemala partía de la ciudad de México y primordialmente de Puebla de los Ángeles, pasando por la ciudad de Antequera para dirigirse a la costa de Oaxaca, en donde Juchitán y Tehuantepec eran los puntos de paso obligados; estas poblaciones proveían de hábiles arrieros a los patachos de mulas, vehículos de rigor para dicha transportación. ${ }^{51}$ En los lomos de estos animales y al cuidado de esos personajes tan especiales que eran los arrieros, irían cuidadosamente embaladas las esculturas guatemaltecas, que despertarían la admiración y la piedad religiosa de los novohispanos.

Principiemos por referirnos a la catedral de Oaxaca, en la que nos encontramos con un San José, de tamaño natural, cuyas vestiduras son movidas por un imaginario golpe de viento, que producen un bello toque barro$\mathrm{co}$, con todas las características de la estatuaria dieciochesca guatemalteca; también se admira una Santa María de Cervelló de tamaño grande, así como una Dolorosa y otro San José de media talla, de extraordinario estofado con intensos rojo y verde, claramente guatemalteco..$^{52}$

En la iglesia de Santo Domingo hay un Ecce homo de tamaño natural que nos parece guatemalteco. Asimismo, en la sacristía de la iglesia conventual de San José de Capuchinas (también llamada Capuchinas de arriba o españolas), que fuera fundada por las monjas de igual advocación provenientes de Guatemala, se encuentra en su sacristía un bellísimo crucifijo de una vara de alto, que tiene todas las características de la escultura

51 Una referencia más exacta de la ruta comercial entre Puebla y Guatemala, con los diversos poblados por los que transitaban las arrias de mulas, se halla en el artículo citado en la nota 1.

52 En las actas del Cabildo Catedralicio de Oaxaca, del 5 de junio de 1778, aparece, según información del Dr. H. Berlín, la siguiente anotación: "Se pide licencia para colocar en la capilla del señor S. Antonio, una imagen nueva del Santo que consiguió de Guatemala". No recordamos haber visto esta escultura en nuestra última visita a la catedral de Oaxaca.

Es importante recordar que en los mismos documentos, con fecha 18 de enero de 1808 , dice el cortesponsal en Guatemala al de Oaxaca que: “... no he mandado poner por obra el Santo Cristo, porque no dice si ha de ser muerto o en agonía, español de Esquipulas," nos parece sumamente interesante señalar los cuatro tipos de Cristo que se habian ido definiendo a través del tiempo en la estancia guatemalteca, pero particularmente la diferencia entre el Cristo con encarnación blanca (español) o monera (Esquipulas). Berlin, op. cit., p. 214. 
antigüeña, así como un San José, imagen de vestir, que es de igual proce-" dencia.

En la iglesia de la Merced hay un Niño de Atocha, vestido y estofado infortunadamente, que es guatemalteco, como en San Agustín hay dos santos de esa orden con atuendo de obispos que son casi seguramente de igual origen. En la iglesia de San Francisco, existen dos bellas escultoras de media talla de San Diego de Alcalá y San José, estofadas, también de escuela antigüeña. Empero, en donde nos encontramos el más espectacular conjunto de escultura barroca guatemalteca es en la llamada iglesia de los Siete Príncipes (Capuchinas de abajo o indias), pues en su altar mayor se encuentran los siete arcángeles, de tamaño de media talla, con las características actitudes teatrales del barroco escultórico guatemalteco, de rica policromía aunque no tanta abundancia de dorado, que deben de ser de fines del siglo XVIII, pues la iglesia se concluyó en 1782.

En la iglesia de los jesuitas, el Dr. H. Berlín nos proporciona los siguientes datos acerca de varias esculturas guatemaltecas que nos sirven para tener mayor idea acerca de los costos de encarnado, el trabajo de esculpir, propiamente dicho o en blanco, así como su envío de Santiago de Guatemala en Oaxaca.

\section{Costo de las estautas}

S. Ignacio en blanco

Encarnación y cajón

Su conducción

S. José con niño en blanco

Encarnación y cajón

Su conducción

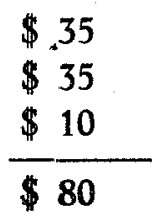

$\$ 49$

$\$ 54.4$ Reales

$\$ 24$

$\$ 127.4$ Reales

S. Juan Nepomuceno en blanco

$\mathrm{Su}$ costo en blanco

Encarnación de ambos ${ }^{53}$ y cajón

$\mathrm{Su}$ conducción

$\$ 104$

53 Desgraciadamente se omitió la advocación de la otra escultura. 
El Niño en blanco

Encarnación y cajón

Su conducción

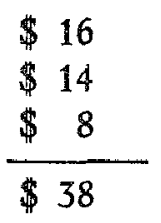

Como se puede notar, en estos envíos no se especifica que hubiera estofado en el acabado de las esculturas, lo que quizás podría indicar, en el caso de las primeras, que fueran de vestir. Por desgracia, el costo de la encarnación está mezclado con el de embalaje. Asimismo, es interesante notar, aparte de San Ignacio de Loyola, la importancia del culto a San José y San Juan Nepomuceno, tan característicos del siglo XVIII y de los jesuitas, toda vez que se trata de papeles que pueden fecharse hacia 1756, según nuestro generoso informante, es decir, en plena época barroca.

Siempre el Dr. Heinrich Berlín en su ya citada obra, incluye numerosos ejemplos de envíos de imágenes religiosas procedentes de Guatemala, que debemos suponer barrocas, por las fechas que abarcan entre 1805 y 1821, es decir, el año de la independencia. Para la ciudad de Oaxaca menciona cerca de 35 esculturas, entre las que se incluyen 7 de Cristo, 5 de la Virgen de Concepción, 4 de la Virgen de Soledad, 1 de la Virgen de Loreto, 2 de María Magdalena, 1 del Niño Dios, 5 de San Juan de la Cruz, 2 de San José, 2 de Santa Teresa, San Joaquín, Santa Ana y los 5 Señores.

Antes de concluir con la mención de escultura de origen guatemalteco en la ciudad de Oaxaca, aludamos, de paso, a la tradición oral de que la conocida imagen de la Virgen de la Soledad de Oaxaca también procede de Guatemala, aseveración que sería importante respaldar con una observación directa y minuciosa de dicha escultura o con algún respaldo documental. Añadamos asimismo, la información proporcionada por Berlín en su misma obra, en la que menciona 14 esculturas enviadas a la población de Tehuantepec desde Guatemala, en el mismo periodo, entre 1805-21, que corresponden a 3 esculturas de Cristo, 6 del Niño Dios y 5 de San José.

En la misma documentación se menciona para la ciudad de Puebla de los Angeles el envío de 8 esculturas, a saber: 4 de la Virgen de Concepción, 2 del Niño Dios y 2 sin especificar. Sin embargo, estamos seguros de que muchos otros envíos no constan en documentación alguna, sino que debieron de hacerse por encomienda directa entre las personas comisionadas para encargar las esculturas y los arrieros o correos que los entregarían a sus destinatarios.

Una rápida observación en la ciudad de Puebla nos lleva a reconocer diversas esculturas de origen guatemalteco, lo cual no es de extrañar si 
recordamos la íntima vinculación entre esta ciudad y la de Santiago de Guatemala. Así, en la catedral pudimos ver un Crucifijo de escuela guatemalteca, aproximadamente de $60 \mathrm{~cm}$. de alto, en uno de los altares colaterales a la derecha, detrás del ciprés. Asimismo, la Virgen del Perdón que se encuentra en el altar frente a la puerta principal, de tamaño natural, policromada pero sin estofe. Mariano Fernández de Echeverría y Veytia (1718-80), en su Historia de la fundación de la ciudad de Puebla de los Ángeles, menciona que en el templo de San Francisco Xavier de la Puebla había unas imágenes de San José y de San Ignacio, ambas guatemaltecas. ${ }^{54}$ En el Museo Bello se encuentran dos preciosas esculturas estofadas, ambas de unos $45 \mathrm{~cm}$. de altura; la primera de Santo Domingo de Guzmán con su característico acabado blanco y negro del hábito con esgrafiados dorados y su encarnado, eminentemente guatemalteco, y la otra es un San Francisco de Asís con el color azulado del hábito franciscano, trabajado a base de delicado esgrafiado dorado y finas flores sobre el fondo aludido. ${ }^{5.5}$

En la ciudad de México hay un número considerable de esculturas guatemaltecas, ${ }^{56}$ muchas de ellas existentes desde hace mucho tiempo, como los ejemplos ya citados de la que perteneció al Conde de San Bartolomé de Xala y la del Marqués de Sierra Nevada, o el bellísimo Misterio del Museo de la Basílica de Guadaupe, en donde se encuentra además una Virgen con el Niño, del siglo XVIII, clasificada como de posible procedencia guatemalteca, así como una Inmaculada que debe de tener cerca de $2 \mathrm{~m}$. de altura y cuyos cabello, rostro, manos y estofado denotan el mismo origen. Rafael Heliodoro Valle cita un San José en la iglesia de las Vizcaínas, en un artículo casi ovidado. ${ }^{7}$

\footnotetext{
${ }^{54}$ No hemos tenido la ocasión de constatar si aún existen estas dos imágenes citadas por Echeverría y Veytia. Esperamos tener próximamente la oportunidad de hacer un recorrido más detenido por la ciudad de Puebla.

${ }^{55}$ Aunque bien puede ser San Isidro Labrador esta escultura, que aparece en el catálogo de la exposición Estofiados en la Nueva España, lámina IX, acaso pudiera ser un lujoso pastor para nacimiento.

${ }^{56}$ Berlín, op. cit ", p. 211. En fecha 3 de marzo de 1805, el oidor don Diego Piloñas que de la Audiencia de México marchaba a la de La Habana con igual cargo pide se le envíen 2 Santos Cristos que había encargado a Guatemala. Pagaría por todo, embalaje y envío incluidos, $\$ 112$ y 6 reales.

${ }^{57}$ Añadamos que en la rica colección del Museo Franz Mayer aparecen en su catálogo, La escultura en México. Siglos XVI al XIX, México, Museo Mayer, 1984, pp. 50-51, 10 imágenes guatemaltecas, así: Virgen y $\mathrm{S}$. José de un nacimiento que conceptuamos dudosos; S. José con el Niño, ángel arrodillado, también de Nacimiento. Virgen Dolorosa típicamente guatemalense, de dimensiones pequeñas. Otra Dolorosa, $S$. Juan y María Magdalena, de tamaño bastante grande que formaban parte de un Calvario. En general, el conjunto iconográfico guatemalteco es bastante representativo.
} 
En la catedral de México nos parecen de procedencia guatemalteca una imagen de la Virgen María de pequeñas dimensiones, y otra que se encon* traba antes en el Museo Religioso de la misma iglesia, según parece ahora en el Museo del Virreinato en Tepotzotlán. Existe allí además una Virgen de la Asunción, en la capilla de la Inmaculada Concepción, que posiblemente sea guatemalense.

En la capilla doméstica de Tepotzotlán hay varias imágenes pequeñas, colocadas en los retablos dorados con espejos, acaso llevados allí por los diversos estudiantes guatemaltecos que concurrieron a dicho Seminario, entre los cuales se encontraba el mismo Rafael Landívar. También hay una Virgen de Dolores estofada no muy fina, de $1 \frac{1}{2} 2$ varas de altura, aproximada; desgraciadamente su rostro está algo retocado.

El libro de la exposición montada por COMERMEX, en 1979, es un buen testimonio de la presencia de esculturas guatemaltecas en México, pues de las ilustraciones en color allí incluídas podemos fácilmente mencionar como de origen guatemalteco las siguientes:

VI. Virgen de la Purísima Concepción, de colección particular; IX. San Isidro Labrador, clasificado como del siglo XVIII, de la colección del Museo Bello de Puebla, que consideramos ser del siglo XVIII; XIII. Santo Domingo de Guzmán, Siglo XVIII, Colección Museo Bello; XXI. Nacimiento, siglo XVIII, de colección particular, que incluye un bellísimo ángel que debió llevar una filacteria con la leyenda habitual referida a la glorificación de Dios y a los deseos de paz a los hombres de buena voluntad; XXIII. Calvario que incluye a Cristo Crucificado, los dos ladrones, Virgen de Dolores, María Magdalena y San Juan; XXV. San Antonio Abad, siglo XVIII, colección particular; XXVI. Nacimiento, siglo XVIII, colección particu$\operatorname{lar}^{58}$

58 De la exposición organizada por COMERMEX en 1979-80 ya aludida, se editó otro catálogo en que aparecen algunas fotografias distintas del que hemos utilizado, de acuerdo con las cuales se podría añadir las siguientes esculturas que podemos identificar como guatemaltecas:

11 Magdalena, siglo XVIII, Col, particular; 14 Calvario, siglo XVIII, Col, particular;; 18 Nuestra Señora de los Dolores, siglo XVIII, Col. particular; 21 Misterio, siglo XVIII, Col. particular; 26 Purísima Concepción, siglo XVIII, Col. particular; 57 Virgen con el Niño, siglo XVIII, Museo de la Basílica de Guadalupe, sobre la que tenemos alguna duda y ya mencionamos; 58-59 San José y la Virgen María, siglo XVIII, Museo de la Basílica de Guadalupe (ya citada por nosotros); 66 San José, siglo XVIII, Col. particular; 67 Dalorosa, siglo XVIII, Col. particular. Todas las esculturas son estofadas y encarnadas y estamos convencidos de que observando otras fotografías podriamos identificar otras de procedencia guatemalteca. Por la época y sus características formales evidentemenet son barrocas. 
En la obra de A. Ussel se incluyen algunas imágenes de la Virgen María que no hemos mencionado y que pudieran ser guatemaltecas por varias de sus características, como las que tiene una Piedad que se encientra en la iglesia de San Fernando de la ciudad de México: el rostro de la Virgen, su estofado, la encarnación de sus manos, y la escultura de Cristo que tiene en su regazo. Asimismo, menciona una Virgen de Dolores de la colección Franz Mayer, de $57 \mathrm{~cm}$. de altura que para nosotros es de Guatemala, pues su talla, estofado y encarnación son evidentemente del mismo origen, asnciándose con dos de las esculturas de la exposición ya aludida de 1979 y con la Virgen de igual advocación que se encuentra en el Museo Nacional del Virreinato, en la capilla doméstica. ${ }^{59}$

A fines de 1987 se montó en el Museo Nacional del Virreinato, en Tepotzotlán, una exposición denominada "Imaginería virreinal Guatemala y México", con materiales provenientes de colecciones nacionales y eclesiásticas de Guatemala, principalmente de la iglesia de la Merced, que sumaron 22 esculturas, más otras 41 de colecciones mexicanas de las cuales 33 eran coloniales, lo que da un gran conjunto de piezas escultóricas que da una idea cabal del esplendor barroco de la escultura colonial de estos dos países. ${ }^{60}$

Aứn cuando sería interminable mencionar esculturas guatemaltecas en el resto de México, incluiremos algunas que nos han sido mencionadas directamente, y otras de las que hemos tenido información en obras publicadas: la Virgen del Carmen de Tenancingo; la Virgen del Carmen de San Luis Potosí y un San Cristóbal del Montecillo, observado por Francisco de la Maza en dicha población. ${ }^{61}$ Según mención de fray José de Arlegui (1749) hay una cabeza y las manos de Cristo en la iglesia franciscana de San Luis Potosí. Existe en la catedral de Durango una Virgen de la Inmaculada Concepción que A. Ussel estima poder ser mexicana, aunque quizá también guatemalteca, lo que también opina Guillermo Tovar de Teresa, ${ }^{62}$ con lo que estamos plenamente de acuerdo. C. Navarrete nos informa que en la catedral de Chihutahua hay una bella imagen del Arcángel San Gabriel, de pequeñas dimensiones, muy característicamente guatemalteca.

${ }^{59}$ Ussel, op. cit , pp. 106-7.

${ }^{00}$ Véase catálogo de la exposición Imaginería virreinal Guatemala y México, México, Museo Nacional del Virreinato, INAH, 1987.

ol Francisco de la Maza, El arte colonial en San Luis Potosi, México, Instituto de Investigaciones Estéticas de la UNAM, 1969, pp. 67.68. Dice el autor que es la mejor escultura religiosa que posee San Luis Potosí y estima que bien pueda ser guatemalteca dada su cali. dad, lo que coincide con la tradición conservada en el propio lugar.

62 Guillermo Tovar de Teresa, México barroco, México, Secretaría de Asentamientos Humanos y Obras Rúblicas, 1981, p. 228. 
Esperamos que este acopio de información acerca de la presencia de esculturas coloniales guatemaltecas en México pueda servir no únicamente para mostrar su considerable cantidad, sino también para incitar a otros historiadores del arte, principalmente a los de nacionalidad mexicana, a emprender nuevas investigaciones que enriquezcan los datos que aquí proporcionamos y que permitan a los guatemaltecos ratificar sus juicios acerca del valor que tiene la escultura colonial de ese país, y, a la vez, que estrechen la interrelación cultural que desde remotos tiempos ha existido entre Guatemala y México. 